\title{
Research of corrosion and mechanical resistance of reinforcement steels designated for operation in hydraulic structures
}

\author{
Mykhailo Sukach ${ }^{1}$, Myroslav Kindrachuk ${ }^{2}$, Valeriy Makarenko ${ }^{1,3}$ \\ ${ }^{1}$ Kyiv national university of construction and architecture \\ Povitroflotskiy Avenue 31, Kyiv, Ukraine, 03037 \\ msukach@ua.fm, orcid.org/0000-0003-0485-4073 \\ ${ }^{2}$ Kyiv National Aviation University \\ Lyubomir Guzara Avenue 1, Kyiv, 03058, orcid.org/0000-0002-0529-2466 \\ ${ }^{3}$ orcid.org/0000-0001-6668-3957
}

Received 04.08.2021, accepted after revision 25.09.2021

https://doi.org/10.32347/uwt2021.11.1802

\begin{abstract}
Analytical inspection showed that with a long service life of reinforced concrete structures of hydraulic structures, their individual elements such as reinforcing bars are destroyed due to insufficient fatigue and corrosion strength of the reinforcement metal. They occur mainly under the action of the main variable loads - bending, vibrations of reinforced concrete slabs, mechanical and erosion of the environment. The main causes of failure of the valve are its rupture and wear due to repeated action of force factors. The surface zone of the reinforcement in connection with concrete is especially intensively destroyed due to weak adhesion strength. The use of low-strength reinforcing steels can also be one of the reasons for the failure of reinforcement joints with concrete. Improving the corrosion and mechanical reliability of reinforced concrete structures of hydraulic structures is possible through the use of: for the manufacture of reinforcing bars which are the main power structure of reinforced concrete economically modified alloy steels, which undergo complex heat treatment and are characterized by high corrosion and fatigue properties. alternating) loads; The resistance against SCRN, VIR and corrosionmechanical fatigue of reinforcing steels intended for the construction industry has been studied.

It was found that the experimental steels, economically modified REE, copper-nickel, especially chromium niobium and vanadium meet the requirements of the International Standard NACE MR 0175-96 on chemical composition and mechanical properties, and steels of grades
\end{abstract}

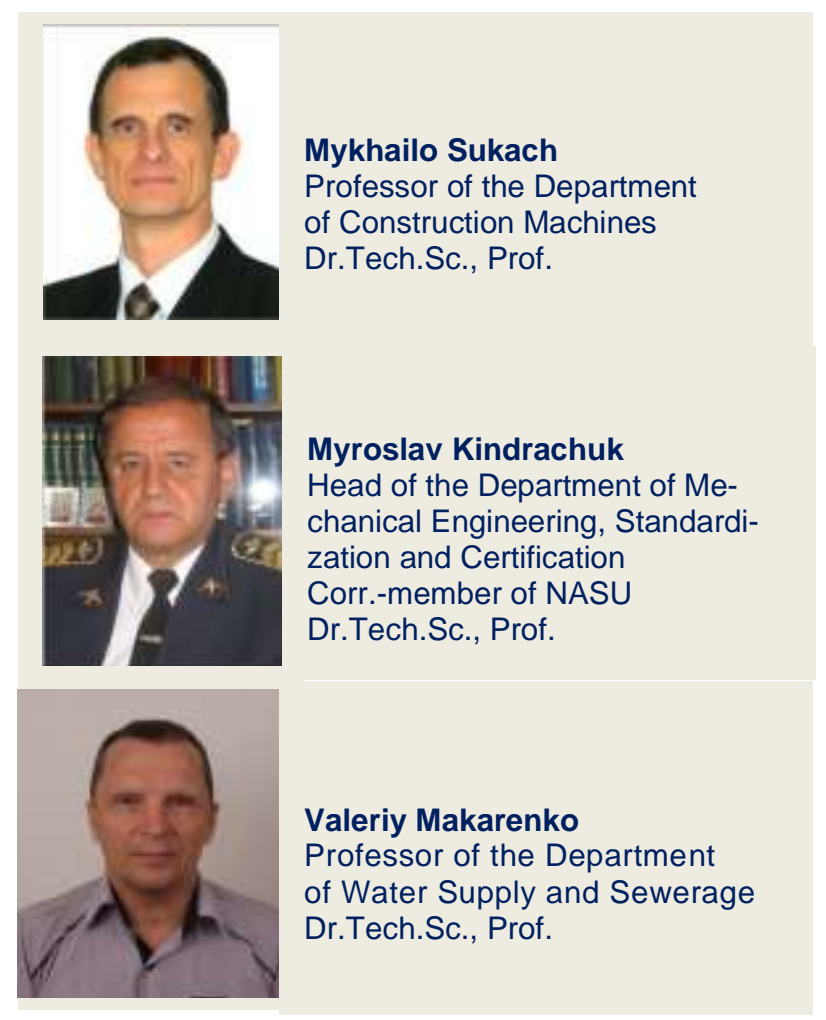

10HSNDA and 20F do not have a sufficiently high resistance SCRN < limits $\sigma_{0.2 \mathrm{~min}}$ ) and corrosionfatigue failure, and steels of grades $20 \mathrm{~F}$ and 06G2B showed low resistance to VIR (CLR> 6\% and CTR> 3\%). Therefore, it is necessary to carry out a full $(100 \%)$ input control of corrosion and mechanical resistance of all materials involved in the manufacture of reinforced concrete structures 
for hydraulic purposes for operation in hydrogen sulfide-containing environment.

Keywords: corrosion destruction, flooding, crack resistance, endurance, fatigue strength.

\section{INTRODUCTION}

It is known [1 - 5] that the resistance of the metal to fatigue failure is characterized by the limit of endurance (fatigue), i.e. it is the highest stress that can withstand the metal without failure at any number of cycles. The endurance limit is most often determined in tests with alternating symmetric cycle $(\mathrm{R}=-1)$, and therefore the endurance limit is denoted by $\sigma_{-1}$.

As a rule, the endurance limit is limited to $10^{7}$ cycles (this number of cycles is called the test base). Thus, it can be noted that the endurance limit is the maximum cycle stress that can withstand the material without destruction at the base number of cycles (for ferrous metals, this base is $10^{7}$ cycles). Then on fatigue curves it is possible to find such important indicator, as durability at fatigue under which accept number of cycles of loading which maintains steel at destruction at a certain pressure $[3,4]$.

It is known from the literature [1] that the endurance limit in metal correlates well with the mechanical properties of metals. Thus, the value of $\sigma_{-1}$ is on average $(0.4 \ldots 0.6) \sigma_{v}$ - for carbon and alloy steels; $(0.3 \ldots 0.5) \sigma_{v}-$ for bronze and brass. This characteristic can be similarly compared with Brinell hardness: $\sigma_{-1}$ $=(0.128-0.156) \mathrm{HB}-$ for carbon steels $(0.168$ $0.222) \mathrm{HB}$ - for alloy steels; $\sigma_{-1}=0.19 \mathrm{HB}$ - for aluminum alloys.

It is known from modern fracture mechanics [2-4] that with increasing number of cycles at any stresses above the endurance limit in metal, the following processes occur sequentially: 1) plastic deformation; 2) the formation of cracks, the cells of which are nonmetallic inclusions (HB); 3) gradual development of some of them with the predominant spread of the main crack; 4) rapid final destruction.

The process of fatigue begins with the plastic deformation of the surface layers of the metal fittings. Moreover, the displacement of dislocations under conditions of re-alternating loads is observed at loads below the elastic limit of the metal. The rate of local plastic deformation during cyclic deformation is several orders of magnitude higher than the rate of deformation under static loading. Dislocation slip begins in grains with a favorable orientation near stress concentrators. As the number of cycles in the surface layers increases, the density of dislocations and the number of vacancies increases. Upon reaching the base number of cycles $\mathrm{N}_{\mathrm{R}}$, a surface reinforced layer of metal is formed with a large number of germinal cracks, the size of which does not reach a critical value. Increasing the number of cycles cannot cause further development of fracture in such a layer. Only when the stresses exceed the crack endurance limit reach a critical length $[5,6]$, after which the process of their discharge into the main crack begins with the spread of the latter.

\section{RESEARCH METHODS AND MATERIALS}

As model media used: NACE medium (5\% $\mathrm{NaCl}$ solution, which contained $0.5 \%$ $\mathrm{CH} 3 \mathrm{COOH}$ and saturated $\mathrm{H} 2 \mathrm{~S} ; \mathrm{t}=22 \pm 2 \mathrm{oC}$; $\mathrm{pH}=3.8 \ldots 4.0$ ); The objects of research were the following steels: 16G2AF; 20F; 15HSNDA; 10HSNDA; 09G2FB; 06G2B and 08HMCHA.

He corrosion rate was determined using the gravimetric method: the test period was 480 hours. Samples cut directly from reinforcing bars with a diameter of $32 \mathrm{~mm}$ were also tested for susceptibility to hydrogen-induced fracture (BIR) according to the International Standard NACE TM-02-90, as such a test is mandatory when choosing a material for the manufacture of responsible hydraulic structures in contact with media, which contain hydrogen sulfide $[1,5]$.

The VIR of rectangular samples $80 \mathrm{~mm}$ long (along the rolling), $\mathrm{W}=12 \mathrm{~mm}$ wide (across the rolling) and thickness $\mathrm{T}$ (determined by the diameter of the reinforcement taking into account the allowance for machining to metallic luster), which were cut directly from the reinforcing bars after rolling. The test involves a 96-hour exposure of stressed samples in a synthetic solution of NACE $(5 \%$ 
$\mathrm{NaCl}$ solution $+0.5 \% \mathrm{CH}_{3} \mathrm{COOH}$, continuous saturation of $\mathrm{H} 2 \mathrm{~S}$ with a bubbling rate of 10 $\mathrm{ml} / \mathrm{min} ; \mathrm{pH}=3 \ldots 4)$, and the minimum volume of the solution was $4 \mathrm{ml}$ per $1 \mathrm{~cm} 2$ of the sample surface [18]. Subsequently, the samples were cut, and the cut surface was polished and etched in a medium of chemical reagents. All detected at magnification x 100 cracks were measured, except those that were at a distance of up to $1 \mathrm{~mm}$ from the surface of the sample.

Based on the measurement results, the coefficients of sensitivity of steel to hydrogeninduced fracture were calculated according to the following formulas: coefficient of crack length $C L R=(\Sigma \mathrm{a} / \mathrm{W}) 100 \%$; the coefficient of crack formation width CTR $=(\Sigma \mathrm{b} / \mathrm{T}) \cdot 100, \%$, where $\Sigma$ a and $\Sigma$ b are the sum of the longitudinal and transverse dimensions of the crack formation, respectively.

According to the International Specification, the following requirements for hydrogen resistance of tubular steels are set: for VIR coefficients of crack length $\mathrm{CLR} \leq 6 \%$ and crack thickness $\mathrm{CTR} \leq 3 \%$.

The susceptibility of reinforcing steels to sulfide corrosion fracture under stress (SCRN) was determined according to the standard NACE TM 01-77 (90) - method A (on cylindrical samples with a diameter of $6.4 \mathrm{~mm}$ ), which allowed the thickness of the reinforcement section [11]. Samples were tested on the installation of the model "Instron" (UK) under load (in each experiment used 5 samples). The ultimate stress $\sigma \mathrm{SSC}$ was determined in order to compare the quality of steels of different brands and valves. Test conditions according to this standard are as follows: duration -720 $\mathrm{h}$ in $5 \% \mathrm{NaCl}$ solution containing $0.5 \%$ $\mathrm{CH} 3 \mathrm{COOH}$ and saturated $\mathrm{H} 2 \mathrm{~S} ; \mathrm{pH}=3 ; \mathrm{t}=22$ $\pm 2 \mathrm{oC}$.

The parameter $\sigma \mathrm{SSC}$ was determined from the dependence $\sigma \mathrm{i}-\lg \tau$ ( $\sigma \mathrm{i}-$ initial load; $\tau-$ time to failure, h), at which the samples are not destroyed on the accepted time base of tests.

The graph of the dependence $\sigma_{i}-\lg \tau$ was built on the minimum values of time to failure under each load, because the use of average values of $\tau$ is unacceptable given the need for guaranteed performance of reinforced concrete structures in technological environments with hydrogen sulfide. The shape and dimensions of the samples for fatigue (multicycle) tests are shown in Fig. 1.

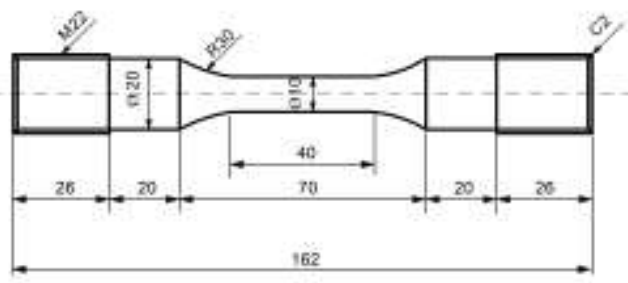

Fig. 1. Sample for tests for fatigue strength (fatigue)

Long-term strength (air tests) and corrosion-fatigue tests were performed on a weighttype installation USMR-6 under load (in each experiment used 5 samples). The basis was 1 $1 \times 10^{6}$ cycles (see Fig. 2 and 3 ).

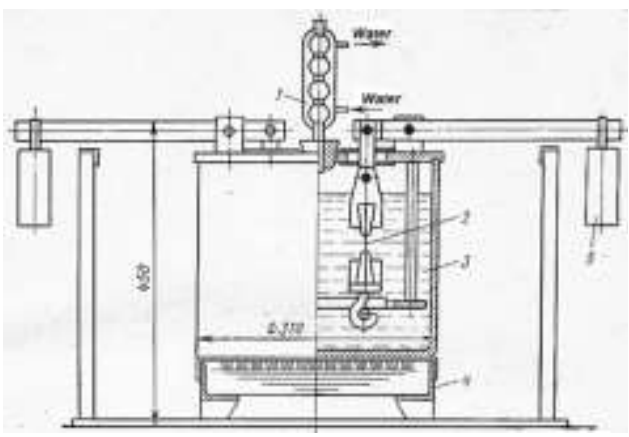

Fig. 2. Schematic diagram of the installation for uniaxial stretching. Designation: 1 - refrigerator; 2 - sample; 3 - capacity; 4 - furnace; 5 - cargo

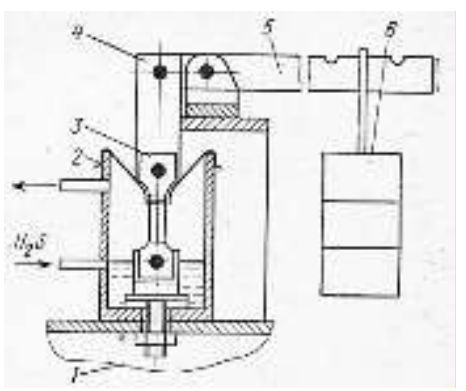

Fig. 3. Test cell in NACE medium (with hydrogen sulfide). Designation: 1 - basis; 2 - cell; 3 sample; 4 - core; 5 - lever; 6 - cargo 
Tests for sulfide cracking were performed according to the method according to the standard NACETM-01-90 [1]. NACE solution was used as the model medium. The basic test period is 720 hours. All samples were tested at a voltage equal to 0.8 of the yield strength of the metal reinforcement, which was determined by the rupture of three samples in air. Tests of samples with an annular groove in the middle were performed by the method of continuous deformation to failure (at low speed $\varepsilon$ $\left.=2+10^{-6} \mathrm{~s}^{-1}\right)$ in a corrosive environment.

\section{The results of experimental research and their discussion}

The results of measurements of the corrosion rate of metal samples of reinforcing steels in the model environment NACE are presented in Fig. 4. Analysis of the data in Fig. 4 shows that the highest corrosion resistance in this environment are characterized by economically modified vanadium, niobium, chromium, nickel and cerium steels, in particular 16G2AF, 09G2FB, 15HSNDA and 08HMCHA, less resistant to corrosion of steel grades $06 \mathrm{G} 2 \mathrm{~B} 1020 \mathrm{~F}$.

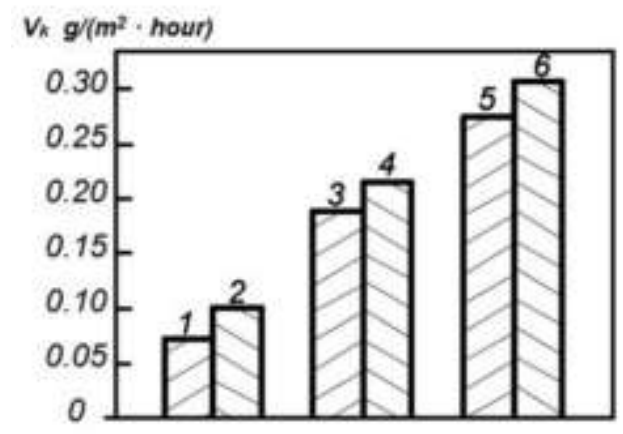

Fig. 4. Corrosion rate diagram of reinforcing steel samples in the NACE model environment. Numbering of samples and grades of steels: 1-16G2AF 2 - 09G2FB 3 - 15HSNDA 4 08HMCHA 5 - 06G2B 6 - 10HSNDA

\section{SKRN research}

The tendency of reinforcing steels to SKRN is graphically shown in Fig. 5. It can be seen that the steels of the following grades 16G2AF, 09G2FB, 15HSNDA, 10HSNDA are characterized by the greatest resistance of SKRN. Steels 20F, 08HMCHA and 06G2B have slightly lower resistance. It is seen that both in the resistance to the corrosion process and in the case of resistance to stress corrosion (SCRN) there is a complete analogy, ie the greatest resistance to SCRN is characterized by steels economically modified with vanadium, niobium, cerium and other useful elements [8-11].

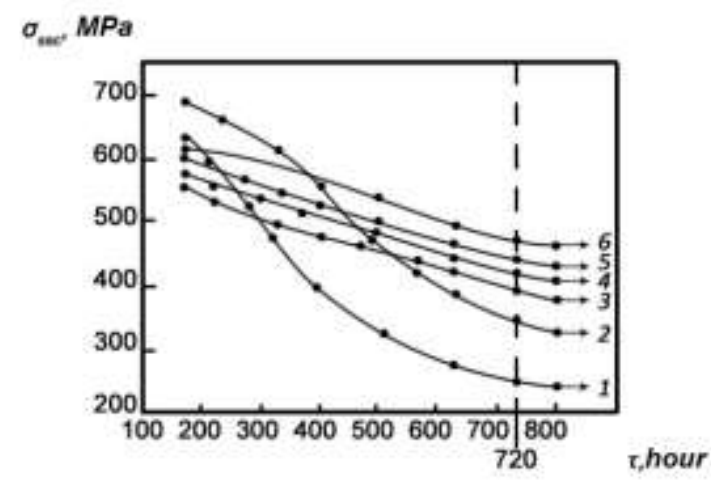

Fig. 5. Susceptibility to sulfide corrosion fracture under stress of reinforcing steels when tested in model environments. The numbering corresponds to the designation on Fig. 3

However, it should be noted that the absolute values of otssc should not yet be used in the design of reinforced concrete structures for critical purposes, for example for hydraulic underground structures due to lack of reliable methods for determining and predicting their fatigue (long-term) strength, as they can change and carbon gas and their partial pressures, $\mathrm{pH}$, ambient temperature, process stops, condition of structures, etc.) $[4,9,12]$. Therefore, in calculations of long-term strength and load-bearing capacity of reinforcing steels of reinforced concrete structures, determining the diameter of reinforcement, the initial parameter may be the minimum allowable value of the yield strength of steel $\sigma_{\min } 0.2$, and the suitability of structural materials is evaluated by ultimate stresses [10]: $\mathrm{ktssc}=\sigma \mathrm{tssc} / \sigma_{\min } 0.2$ (Fig. 6).

It is considered that steel is suitable for the manufacture of fittings and operation in technological environments with a high content of corrosive components, including hydrogen 
sulfide (up to 20 mol.\%), When $\mathrm{k}_{\mathrm{tssc}} \geq 0.8[10$ $-12]$.

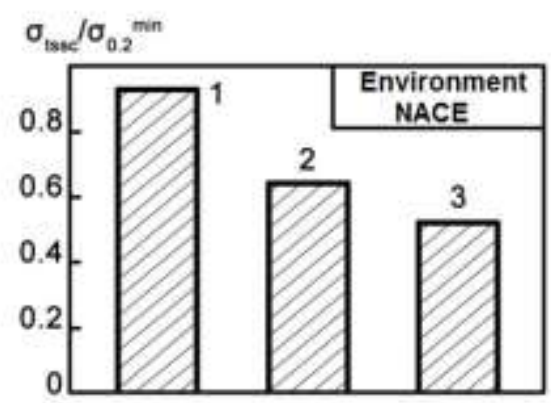

Fig. 6. Threshold values of resistance to sulfide corrosion failure under stress of reinforcing steels of reinforced concrete structures of long service life in the NACE environment: 1 - steel 16G2AF; 2 - 09G2FB 3 - steel 20F. The deviation of the values of $\sigma$ tssc does not exceed $10 \%$

From the above experimental results it is seen that the highest corrosion resistance against SCRN is characterized by steel grade $16 \mathrm{G} 2 \mathrm{AF}$ and $09 \mathrm{G} 2 \mathrm{FB}$, and steel grade $20 \mathrm{~F}$ has low values of the coefficient $\mathrm{k}_{\mathrm{tssc}}=0.45 \ldots 0.60$ (see Fig. 4). Thus, the performance of steels for reinforcing steels for construction purposes, which is estimated by the parameters $\mathrm{k}_{\mathrm{tssc}}$ and $\sigma_{\text {tssc }}$, is different.

It should be noted that the results of the resistance study of SCRN steels correlate well with the data of the gravimetric corrosion rate determination method both in NACE solution and in $\mathrm{NaCl}$ solution (see Fig. 4).

Thus, it can be generalized that economically modified steels 16G2AF and 09G2FB, which contain low concentrations of harmful impurities of sulfur, phosphorus and hydrogen, are characterized by high resistance to uniform corrosion, including against SCRN, and therefore can be recommended for use in the production of reinforcement for reinforced concrete structures of hydraulic structures.

\section{VIR research}

The results of VIR studies of reinforcing steel (without application of load) showed that in the NACE solution is hydrogen cracking and surface swelling of some steels grade 06GB and 20F. The calculated values of VIR hydrogen cracking indicators for these steels are: $\mathrm{CLR}=3.2 \ldots 4.8 \%$; $\mathrm{CTR}=6.9 \ldots 10.8 \%$. It is established that steels 16G2AF, 09G2FB, 08HMCHA, 15HSNDA- meet the requirements of Technical conditions [11 - 17].

\section{Study of corrosion fatigue (long-term strength)}

In the course of experimental researches the following (Fig. 7) is established:

1) NACE medium, which contains hydrogen sulfide, more than 1.75 times, reduces the fatigue limit of samples with a diameter of 5 $\mathrm{mm}$ from steel grade 09G2FB (from 700 to $400 \mathrm{MPa}$ ).

2) Hydrogen sulfide-containing medium NACE almost 5 times (from 490 to $200 \mathrm{MPa}$ ) reduces the fatigue limit of steel 10HSNDA.

3) The highest values of long-term strength showed experimental steels in NACE. Economical modification of REM steel (08HMCHA steel) allowed to increase the corrosion and fatigue strength even when tested in an aggressive NACE environment more than 2 times compared to conventional steel grade 10HSNDA (see Fig. 7). Thus, the conditional limit of corrosion fatigue of steels 15HSNDA and 06G2B in hydrogen sulfidecontaining medium at 1 million cycles (base of many cycle tests) - (curves 4 and 6 in Fig. 7) increased from 190 to 280-290 MPa.

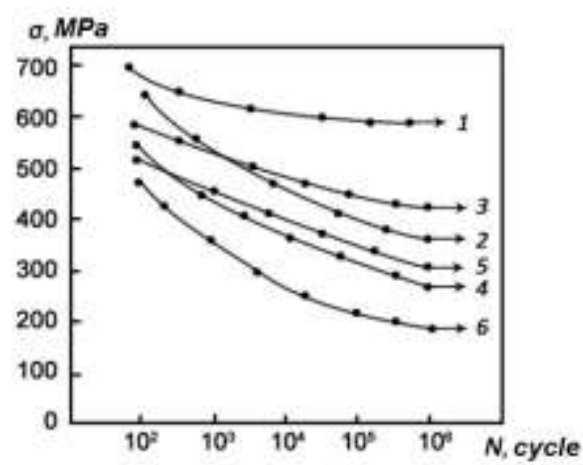

Fig. 7. Corrosion fatigue curves of reinforcing steel samples in NACE solution: See steel grade designation. Fig. 3 
From the above experimental results it can be generalized that the positive effect of doping with modifying impurities is observed stably when using them in low-alloy steels in a limited amount mentioned above. Their further increase causes clogging of the metal with large particles of silicates or oxides and oxysulfides of cerium niobium and vanadium, without affecting the total number of nonmetallic inclusions.

In domestic and foreign studies by a number of authors it is noted that the reasons for the decrease in resistance to SCRN and VIR of some carbon and low-alloy steels may be the presence of silicates, as well as microleaching of individual alloying elements or impurities, or violation of thermomechanical modes of reinforcement rods $[12,13]$.

Therefore, the results of laboratory and experimental studies have shown that economically modified steels are characterized by high corrosion and fatigue strength and can be used in reinforced concrete structures in contact with aggressive environments of hydraulic systems. The obtained results of experimental researches can be useful for designers at development of projects on use of reinforced concrete products in hydraulic engineering constructions, for example, underground sewer systems, ie their careful check in the conditions of industrial construction is required [15-17].

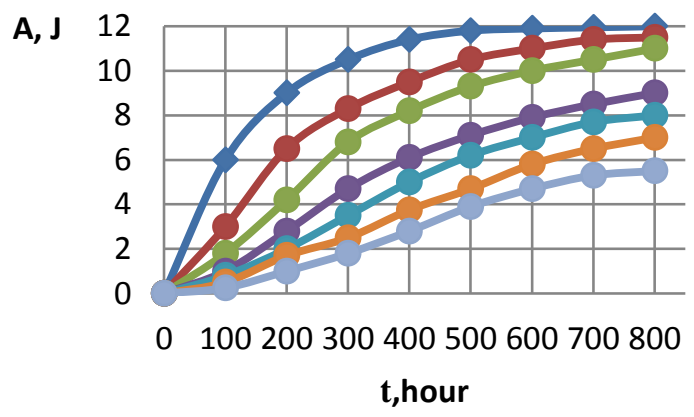

Fig. 8. The work of corrosion destruction of reinforcement samples in the NACE environment. Designation of reinforcing steels: 1 - 16G2AF, 2 - 09G2FB, 3 - 15HSNDA, 4 - 08HMCHA, 5 - 06G2B, 6 - 10HSNDA, $7-20 \mathrm{~F}$
The results of tests of corrosion destruction of reinforcing steel samples in the NACE environment are shown in Fig. 8.

Analysis of the data shown in Fig. 8 makes it possible to note that the greatest resistance to sulfide-corrosion fracture have reinforcing steels brands 16G2AF, 09G2FB, 15HSNDA. The other brands 08HMCHA, 06G2B, 10HSNDA and $20 \mathrm{~F}$ have less resistance to corrosion damage.

\section{CONCLUSIONS}

1. The analytical inspection showed that at long service life of reinforced concrete designs of hydraulic engineering constructions their separate elements for example reinforcing cores are destroyed owing to insufficient fatigue-corrosion durability of metal of armature. They occur mainly under the action of the main variable loads - bending, vibrations of reinforced concrete slabs, mechanical and erosion of the environment. The main causes of failure of the valve are its rupture and wear due to repeated action of force factors. The surface zone of the reinforcement in connection with concrete is especially intensively destroyed due to weak adhesion strength. The use of low-strength reinforcing steels can also be one of the reasons for the failure of reinforcement joints with concrete.

2 . Increasing the corrosion-mechanical reliability of reinforced concrete structures of hydraulic structures is possible through the use of: for the manufacture of reinforcing bars which are the main power structure of reinforced concrete economically modified alloy steels, which undergo complex heat treatment and are characterized by high corrosionfatigue properties. cyclic (alternating) loads;

3. Resistance against SCRN, VIR and corrosion-mechanical fatigue of reinforcing steels intended for the construction industry is investigated. It was found that the experimental steels, economically modified REE, coppernickel, especially chromium niobium and vanadium meet the requirements of the International Standard NACE MR 0175-96 on chemical composition and mechanical properties, and steels of grades 10HSNDA and 20F do not 
have a sufficiently high resistance SCRN $<$ limits $\cdot \sigma 0.2 \mathrm{~min}$ ) and corrosion-fatigue failure, and steels of grades 20F and 06G2B showed low resistance to VIR (CLR> 6\% and CTR $>3 \%$ ). Therefore, it is necessary to carry out a full $(100 \%)$ input control of corrosion and mechanical resistance of all materials involved in the manufacture of reinforced concrete structures for hydraulic purposes for operation in hydrogen sulfide-containing media.

\section{REFERENCES}

1.Makhutov N.A., 1981. Deformation criteria of destruction. Mashinostroenie, 272 (Russian).

2.Archakov Yu.I., 1980. Hydrogen corrosion of steel. Metallurgy (in Russian).

3.Atomic mechanism of destruction, 1983. Mir. 660 (in Russian).

4.Kalachev B.A., 1985. Hydrogen fragility of metals. Metallurgy, 216 (in Russian).

5.Meshkov Yu.Ya., 1985. Physical foundations of the strength of steel structures. Kiev, Naukova Dumka, 266 (in Russian).

6. Petrov L.N., Sopronyuk N.G. 1988. Corrosionmechanical destruction of metals and alloys, Kiev, Naukova Dumka, 488 (in Russian).

7.Moskvin V.M. , 1980. Corrosion of concrete and reinforced concrete methods of their protection. Stroyizdat, 538 (in Russian).

8. Makarenko V.D., Mangura A.M., Sizonenko A.V., Litvyak O.L. 2019. Mechanisms of corrosion-carbon corrosion of structural pipe steels for naphtha and gas filling Modernization and engineering development of resource-saving technologies in the form of packaging and processing of brown copal ins. Collective monograph. Petro Shan, Rumania, Universities Publishing, 424 (57-70).

9. Makarenko V.,Vynnykov Y., Liashenko A., Petrash O., 2019. Hydrate Formations Modeling for the Oil and Gas Facilities Reconstruction, Proceedings of the 2nd International Conference on Building Innovations. ICBI Lecture Hydrate Formations Modeling for the Oil and Gas Facilities Reconstruction Notes in Civil Engineering, vol 73. Springer, Cham. 651-658.

10. Boyko A.V., Makarenko V.D, Maximov S.Yu., 2021. On some mechanical characteristics of structural steels of cooling systems of long operation. Problems of durability, No.2 (470), 77-81 (in Russian).
11.Makarenko, V.D., \& Morgun, I.D., 1991. Special features of the effect of barium on the mechanical properties of metal deposited in welding with calcium fluoride electrodes. Welding International, 5(9), 726-728 (in Russian).

12.Pokhodnya I.K., Ponomarev V.E., Milichenko S.S., Skorina N.V., Makarenko V.D., Marchenko A.E., \& Gorpenyuk, V.N., 1987. Effects of type of binder and its composition on the welding and properties of electrodes with basic coatings. Welding International, 1(2), 116-118 (in Russian).

13.Kreshchanovsky I.S., Sidorenko M.F., 1970. Modification of steel, Metallurgy. 296 (in Russian).

14.NACE Standard TMO 177-90, 1990. Standard Test Method Laboratory Testing of Metals for Resistance to Sulfide Stress Cracking in $\mathrm{H}_{2} \mathrm{~S}$ Environments, NACE Houston.P.O. Box 218340, 22.

15.MSKR-01-85, 1985. Test procedure for resistance to hydrogen sulfide stress corrosion cracking. Publishing house of the State Committee for Science and Technology of the USSR, 8.

16.Makarenko V.D., Shatilo S.P., 1999. Increasing desulphurisation of the metal of welded joints in oil pipelines. Welding International. 56-61 (in Russian).

17.Makarenko V.D., Beljaev V.A., Protasov V.N., Shatilo S.P., 2000. Mathematical model of the mechanism of resistance of welded joints in oil and gas pipelines to static hydrogen fatigue. Welding International, 83-88 (in Russian).

18. Sukach M.K., 2018. Theoretical foundations for the calculation of staple-shaped leaf springs. Transfer of Innovative Technologies, Vol.1, No.2, 40-50. https://doi.org/10.31493/tit1812. 0201.

19. Horbatenko Y.G., 2020. The production of the splash phenomenon, as a way of dissipating the energy of a gravitational wave. Underwater Technologies. Vol.10, 58-67.

20. Sukach M.K., 2021. The Staple-ShapePlate Springs Engineering Calculation Method. Science and Technique. 20 (3), 268-274, https://doi.org/10.21122/2227-1031-2021-20-3. 


\section{Исследование коррозии и механической устойчивости арматурных сталей, предназначенных для эксплуатации в гидравлических сооружениях}

\section{Михаил Сукач, Мирослав Киндрачук, Валерий Макаренко}

Аннотация. Аналитическое обследование показало, что при длительном сроке эксплуатации железобетонных конструкций гидротехнических сооружений отдельные их элементы, такие как арматурные стержни, разрушаются из-за недостаточной усталостной и коррозионной стойкости металла арматуры. Они возникают в основном под действием основных переменных нагрузок - изгиба, вибрации железобетонных плит, механической и эрозии окружающей среды. Основные причины выхода клапана из строя - его разрыв и износ из-за многократного действия силовых факторов. Поверхностная зона арматуры в связи с бетоном особенно интенсивно разрушается из-за слабой прочности сцепления. Использование малопрочных арматурных сталей также может быть одной из причин разрушения стыков арматуры с бетоном. Повышение коррозионной и механической надежности железобетонных конструкций гидротехнических сооружений возможно за счет применения: для изготовле- ния арматурных стержней, являющихся основной силовой конструкцией железобетонных экономически модифицированных легированных сталей, которые проходят сложную термическую обработку и характеризуются высокой коррозионные и усталостные свойства. переменные) нагрузки; Изучена стойкость к SCRN, VIR и коррозионно-механической усталости арматурных сталей, предназначенных для строительной индустрии.

Установлено, что опытные стали, экономически модифицированные РЗЭ, медноникелевые, особенно хромониобий и ванадий соответствуют требованиям международного стандарта NACE MR 0175-96 по химическому составу и механическим свойствам, а стали марок 10ХСНДА и 20Ф не имеют достаточно высокое сопротивление SCRN < предела. $\left.\sigma_{0,2 \min }\right)$ и коррозионно-усталостное разрушение, а стали марок 20F и 06G2B показали низкую стойкость к VIR (CLR> 6\% и CTR> 3\%). Поэтому необходимо проводить полный (100\%) входной контроль коррозионной и механической стойкости всех материалов, задействованных при изготовлении железобетонных конструкций гидравлического назначения для работы в сероводородсодержащих средах.

Ключевые слова: Коррозионное разрушение, затопление, трещиностойкость, выносливость, усталостная прочностью. 